\title{
Video oyunlarında oyuncunun hikayeye etkileri ve anlatı odaklılık: Andrzej Sapkowski'nin Witcher roman serisinin interaktif bir video oyununa dönüşümü
}

İlker ŞENER ${ }^{1}$

Alper KELEŞ²

\begin{abstract}
APA: Şener, İ; Keleş, A. (2020). Video oyunlarında oyuncunun hikayeye etkileri ve anlatı odaklılık: Andrzej Sapkowski'nin Witcher roman serisinin interaktif bir video oyununa dönüşümü. RumeliDE Dil ve Edebiyat Araşttrmaları Dergisi, (18), 362-377. DOI: 10.2900o/rumelide.705964
\end{abstract}

\section{$\ddot{O} \mathbf{z}$}

Bu çalışmada birçok farklı medya türünün bir araya gelerek oluşturduğu hikâye tabanlı video oyunları anlatı düzleminde incelenmektedir. Söz konusu incelemede medyalararasılık kavramından yola çıkılarak, bu alanın yöntem ve kavramlarıyla Witcher 3 video oyununda tespit edilen medyalararas bulgular üzerinden çeşitli analizler yapılmaktadır. Çalışmanın ilk bölümlerinde naratoloji ve ludoloji gibi video oyunlarıyla yakından ilgili kavramlara açıklık getirilmekte, roman uyarlaması video oyunları, açık dünya ve rol yapma oyunları gibi birbirinden farklı görünen türlerin ne tür ilişkiler içerisinde olduklarına değinilmektedir. Ayrıca video oyunlarını hikâye anlatma odaklı dijital anlatı öğelerine dönüştüren faktörlere Witcher 3 video oyunu üzerinden örneklemelerle yer verilmektedir. Çalışmada ayrıca yer verilen ludoloji kuramının hikâye odaklı oyunları incelemede niçin yetersiz kaldığı açıklanmaya çalışılmakta ve anlatı odaklılık kuramının video oyunlarına yönelik bakış açısı sergilenmektedir. Video oyunlarına yaklaşımda yöntemsellik sorunları, video oyunlarındaki mesaj aktarım süreci ve diğer medyalarla olan biçimsel farkları netleştirilerek video oyunlarında roman içerikleri ve oyun hikâyesinin oyuncunun etkileşimi ile ne şekilde değişikliklere uğradığı örneklerle gösterilmektedir. Öte yandan eski medyalar olarak nitelendirilebilecek romanlardan uyarlanan dijital medyaların ne tür medyalar oldukları açıklanmaktadır. Video oyunlarında ve romanlarda alıcının/oyuncunun/okurun konumu meselesi üzerinde durulmakta, okur ve oyuncu odaklı aktarım irdelenmektedir. Bu çalışma ayrıca edebiyat bilim ve sosyal bilimler alanlarında teknoloji çağının dijital anlatı odaklı medyaları olarak tanımlanan video oyunlarının bilimsel araştırma sahasındaki yerinin de belirlenmesi açısından etkin bir rol üstlenmektedir.

Anahtar kelimeler: Naratoloji, medyalararasılık, video oyunları, roman uyarlamaları.

\section{Gamer's effects on plotline of a game story and narration orientation: Transformation of Andrzej Sapkowski's Witcher novel series into an interactive video game}

\begin{abstract}
In this study, you will see the analysis of story-based video games formed by many different genre of video games. The study was constituted through intermediality indications in Witcher 3 video game and the methods and the notions of intermediality. In the first part of the story, you will see the references of narratology and ludology in the way of analyzing the video games and you will see the

1 YL Öğrencisi, Sakarya Üniversitesi, Sosyal Bilimler Enstitüsü, Alman Dili ve Edebiyatı ABD (Sakarya, Türkiye), ilkersn@gmail.com, ORCID ID: 0000-0001-8911-8643 [Makale kaytt tarihi: 07.02.2020-kabul tarihi: 20.03.2020; DOI: 10.29000/rumelide.705964]

2 Dr. Ö̆gr. Üyesi, Sakarya Üniversitesi, Fen Edebiyat Fakültesi, Alman Dili ve Edebiyatı Bölümü (Sakarya, Türkiye), akeles@sakarya.edu.tr, ORCID ID: oooo-0oo3-1050-3843
\end{abstract}


relations of book adaptations, open world and role playing games which differentiate in forms. Also it will explain how the video games become a story-telling-based digital narration and how Witcher 3 illustrates kind of narration just mentioned.Study will discuss how the Ludology by itself cannot measure up while analyzing story-based video games. It will also show how the Narratology supports story-based video games while analyzing them. The study will show that there is methodological problems when it comes to analyze the video games and it will try to clarify those problems. The process of the message transferring in video games and the differences in relation to the other media means will be discussed in the study. It will exemplify how the story in the game and the story in the book undergo a change by the players' interaction. It will be discussed what the role of a player is and what the role of the digital media being adapted from the book is in the process of game story-telling and it will be discussed the contents of the narration in terms of player and reader as well. The study will contribute to scientific field of social sciences and literary science about the video games which is considered to be a story based digital media of nowadays technological world.

Keywords: Narratology, intermediality, video games, book adaptations.

\section{Giriş}

Video oyunları üzerine yapılan çeşitli çalışmalar incelendiğinde, video oyunlarının yalnızca eğlence unsurları olmak yerine bunun bir adım daha ötesine geçilerek "yeni medya" olarak tanımlandıkları ve artık daha detaylı ele alındıklarını görülmektedir. Bugün video oyunları endüstrisi oldukça gelişmiş bir endüstri haline gelmiştir. Neredeyse her evde bulunan bilgisayarlar, oyun konsolları hatta cep telefonları bile video oyunlarını oynamak için birer araç olarak kullanılmaktadırlar. Sandy Douglas'ın geliştirdiği OXO (1950) isimli video oyunu, tarihte bilinen ilk video oyunudur. Oyuncu yan yana 3 adet $\mathrm{x}$ yapmaya bilgisayar da 3 adet $O$ yapmaya çalışır, önce bitiren kazanmaktadır. Oyun endüstrisi ortalama 67 yllık gelişiminin sonucunda günümüzde gerçeğe yakın bir deneyim sunmakta hatta sanal gerçeklik sistemleri ile oyuncuyu direkt olarak oyunun içine alabilmektedir. Video oyunlarında birçok tür vardır (bkz. Can ve Türkmen, 2017: 409-412) fakat bu çalışmanın odak noktasındaki video oyun türleri, rol yapma ile açık dünya türlerinin birleşiminden meydana gelen hikâye odaklı oyunlardır. Bu tür oyunlar içerik olarak bir çerçeve hikâyenin (Alm: Rahmenerzählung) üzerine kurulmuşlardır. Çerçeve hikâyenin içerisinde çeşitli bölümlerden oluşan görevler oyuncuya oyunun ana hikâyesini sunmaktadırlar, oyuncu oyunda yerine getirdiği görevlerde ilerleme kaydettikçe oyunun hikâyesine vakıf olmaktadır. Açı dünya konsepti oyuncunun hikâyede özgürce dolaşıp video oyun evrenini keşfetmesine olanak verirken, rol yapma sistemi oyuncunun evrendeki tüm karakterlerle etkileşime geçmesine, kendi istediği gibi kararlar almasına imkân vermektedir. Video oyunlarında interaktif bir etkileşim içerisinde olan oyuncunun romanlardan uyarlanan hikâyeleri ne şekilde yönlendirdiği sorusu üzerinde durulacak olan bu çalışma video oyunlarına medyalararası bir bakış niteliğini taşımaktadır.

\section{Naratoloji ve Ludoloji}

Frasca (2003:221), araştırmasında video oyunları alanında 2001 yılında kurulan Game Studies isimli video oyunlarını akademik alanda ele alan ilk bilimsel dergi olduğunu, video oyunları üzerine yapılan kapsamlı çalışmaların da artmasına sebep teşkil ettiğini belirtmektedir. Aarseth (2001), bahsi geçen dergide yayınlanan ilk makalesinde edebiyat ve sinema araştırmacılarının video oyunlarını kendi alan sınırları içinde analiz etmelerini ve oyunlar üzerine yapılacak olan çalışmaların video oyun araştırmalarına ait özel bir alanda incelenmesine engel olduklarını öne sürmüştür. Video oyunları ile ilgili araştırma kapsamında birçok çalışma ve tartışma vardır, tartışmaların sebebi ise video oyunlarının 
Gamer's effects on plotline of a game story and narration orientation: Transformation of Andrzej Sapkowski's Witcher novel series Into an interactive video game / İ. Şener; A. Keleş (pp. 362-377)

incelenmesinde sabit bir kuram bulunmaması ve video oyunlarına ne şekilde bakılacağı ile ilgili karşıt görüşlerdir. Bir taraf video oyunlarını bütünsel olarak ludolojik 3 açıdan incelemeyi savunurken, diğer taraf ise anlatısal olarak naratolojik4 açıdan ele almak gerektiğini savunmaktadır. Ludologların sadece oynanışa ve oyunun bütünselliğine bakarak öykü ve anlatı gibi oyunun oyuncuyu içine çeken unsurlarını göz ardı eden bakış açısı karşısında, naratoloji kuramının destekçilerinin oyunu anlatı olarak inceledikleri görülmektedir. Ludologlar anlatıdan bağımsız incelemek istedikleri oyunları türlerine göre ayırmalıdırlar. Demirbaş (2017:353), hikâye odaklı oyunların öykü anlatma amacı taşıdıklarını ve dijital bir hikâye anlatma medyası olarak da görülmeleri gerektiklerini belirtmektedir. Video oyunlarında anlatı odaklılık ve oyunbiçimsellik tartışmalarının artması aslında bir bakıma video oyunları üzerine yapılan çalışmaların artışı ile doğru orantılı olarak görülebilir. Yine de video oyunları bilimsel alanda bir bütün olarak ve anlatısal öğelerden bağımsız incelenemeyecek kadar fazla anlatı unsuruna sahiptirler. $\mathrm{Bu}$ önerme çalışmanın Witcher 3 video oyunu incelemesi üzerinden elde edilen veriler ile erişilen sonuçlara dayandırılmaktadır, bu sonuçlar makalenin son bölümünde karşılaştırmalı inceleme örnekleri olarak verilecektir.

Video oyunlarının incelenmesi ile ilgili günümüzde halen sağlam temelleri olan bir metodoloji oluşturulamamıştır. Aarseth (2003:6-7), Özellikle rol yapma türündeki oyunlar performans odaklı medyalar oldukları için kişiden kişiye içerik olarak değişkenlik gösterdiklerini, bu da video oyunlarını içerik yönünden inceleme sorunsalını ortaya çıkardığını öne sürmektedir. 200o'li yıllar sonrasında teknolojinin de hızının artarak bilgisayar endüstrisindeki ilerlemesi video oyunlarına yansımaktadır. $\mathrm{Bu}$ süreçte video oyunlarının içerik sunma şeklini 3 boyutlu grafikler ve çok daha geniş kapsamlı sanal evrenlerle farklı boyutlara taşıdığı görülmektedir. Tüm bunların yanı sıra geniş kapsamlı evrenlerdeki hikâyeler de oyuncuya sanal bir yaşantı sunmakta, oyuncunun hikâyeleri deneyimleme sürecinde diğer medyalara nazaran daha etkili içerik aktarımı yapıldı̆̆ı görülmektedir. Video oyunları bilimsel alanda yeni medya adı altında ele alınmaktadır. Yeni medyanın iletişim araçlarında teknolojinin etkisi ile gelinen son nokta olduğu söylenebilir. Eğitim bilimleri kapsamında öğrenme ve edinim alanında sık sık örneği verilen Edgar Dale'in (1969) yaşantı konisinde okunan bir metinden ziyade yaparak, yaşayarak öğrenmenin (sanal yaşantı ve simülasyonlar da benzer şekilde ele alınabilir) daha kalıcı bir öğrenme türü olduğu bilinmektedir. Bunun yanı sıra Kaya (1997:1-65) öğrenmede görsel ve işitsel materyallerin kalıcı öğrenme sağladığını da vurgulamaktadır. İletişim sürecinde mesaj aktarımını başarılı ve kalıcı izli olarak yerine getirebilen sistemlerden birisinin simülasyon, yani sanal gerçeklik içerisinde sanal yaşantı ortamında bilgi aktaran sistemler oldukları bilinmektedir. İletişimde bu kadar başarılı bir medyanın hikâye aktarımdaki gücünün göz ardı edilmesi ve bilimsel alanda ötelenmesi sıkıntılı bir yaklaşımdır. Öyle ki video oyunlarının da mesaj verme kaygısı taşıyan konulara sıkça değindiği görülmektedir. Denizel (2012:120-135), "Sanatın Yeni Evresi Olarak Video Oyunları" isimli makalesinde video oyunlarındaki sanatsal öğeleri "Sanat Felsefesi Bağlamında Bilgisayar Oyunlarının Sanatla Bağdaşımı" başlığı altında toplamıştır. Denizel, video oyunlarında klasik kompozisyon kuralı, Grek idealizmi, formalizm, maniyerizm, sinematografi, ütopya ve ütopyacılık, katharsis, fütürizm, altın oran, ikonografi, enformasyon, fantezi gibi akımları ve sanat formlarını tespit etmiştir. Bu sanat formlarının video oyunlarında kullanımı ve bir hikâyenin içerisine yerleştirilerek oyuncuya aktarılması video oyunlarının da sanatsal öğelere sahip olan birçok sanatçının ortak eseri olarak nitelendirilebileceğini göstermektedir. Video oyunları geliştikçe ve içlerine entegre olan sistemler arttıkça incelenmeleri daha da zorlaşmaktadır. Consalvo ve Dutton (2006:1-6), video oyunlarının incelenmesi için araştırmacının başka oyuncuları izlemesi, oyunu araştırmacının oynaması, oyunun yapımcılarının dokümanlarından

3 Ludoloji: Naratolojiye karşıt bir kuramdır, oyunu biçimsel olarak incelemek gerektiğini öne sürer ve oyunları anlatısal içerikten bağımsız olarak incelemeyi savunur (Demirbaş,2017: 353).

N $\quad$ Naratoloji: Video oyunlarının hikaye anlatma odaklı medyalar olabileceğini öne süren kuramdır (Demirbaş,2017: 353). 
yola çıkarak araştırılması gerektiğini öne sürmektedir. Witcher 3 video oyunu incelemesinde de Consalvo ve Dutton'ın önerdiği yönteme benzer bir yol izleyerek yaklaşıldığını ifade etmek mümkündür. Video oyunlarını naratolojik açıdan ele alan çalışmanın inceleme alanı medyalararasılık olarak belirlenmiştir, medyalararasılık alanında medya kavramına ve video oyun medyalarına da değinmek gerektiğini belirtmek mümkündür.

\section{Medyalararasılık ve video oyunu medyası}

Medyalararasılık (Alm: Intermedialität) teknolojinin gelişmesi ile birlikte daha da önem kazanmış bir disiplin haline gelmiştir. Medyalararasılık ve video oyunları bağlantısını kurmadan önce medya kavramını tanımlamak yerinde olacaktır. Zira medyalararasılık kavramının doğru tanımlanması ve aktarılması çalışmanın hangi temeller üzerinden bulgulara ulaşacağını gösterme noktasında önem arz etmektedir. Medya kavramı "aracılık eden" anlamına gelen Latince kökenli "medium" kavramından türemiş ve kısaca insanlar arasında iletişimi sağlayan araç anlamında kullanılmaktadır, bu noktada en başta yazı, gazete, dergi, radyo, edebiyat, tiyatro ve diğer sanat dallarının tümü (bu çalışma örneğinde de görüldüğü gibi video oyunları da) birer medya olarak tanımlanmaktadır. Bugün ise bakıldığında "medya" kavramı kimilerince yalnızca basın-yayın organlarını kapsayan bir tanımlamaymış gibi zaman zaman kullanılmaktadır (krş. Aytaç, 2005:9 ve Kayaoğlu, 2009:28). Bu noktada bir iletiyi taşıyan ve kişilerarası iletişimi sağlayan film, edebiyat, heykel, fotoğraf, radyo, gazete gibi çeşitli alanlardan medyalara rastlamak mümkündür. İşlevsel olarak bir ileti, bir mesaj taşıyan tüm iletişim araçları gibi video oyunları da bir hikâye anlatan, görsel, işitsel ve interaktif bir medyadır. Elbette diğer medyalar ile karşılaştırıldığında interaktiflik ve dijitalize edilmiş sanal evren gibi bazı farklar ortaya çıkmaktadır. Karmaşık bir yapısı olan, sayısal ve kodlamaya bağlı bir tarafı olan video oyunu medyaları aynı zamanda anlatı odaklı medyalar olarak da görülmektedirler. Video oyunları tıpkı filmler gibi en çok yazınsal medyalarla (edebiyat medyası) iç içe giren medyalar olarak nitelendirilebilirler. Medyaların birbirleri ile olan ilişkileri ise medyalararasılık kapsamında ele alınmaktadır. Bu noktada metinlerarasılık kavramı ile benzerlikler taşıyan medyalararasılık kavramı, metinlerarasılı̆̆ın yaptığı gibi araştırma alanını yalnızca metinler üzerinden değil, farklı medyaları birbirleriyle olan ilişkilerini incelediği için metinlerarasılık kavramını bir ileriki aşamaya taşımaktadır (krş. Keleş, 2017:77).

Bulduk ve Canatak (2019: 16-17), birbirinden farklı medyaların birbirlerini dönüştürerek yeni bir medya oluşturmaları, hipertextlerden hiper romanların oluşumu, medyaların dijitalize edilerek yeni medyalar ortaya çıarmaları ve edebiyatın farklı medyalar ile sentezlenmesi konularının medyalararasılık bağlamı içerisinde incelendiğini vurgulamaktadır. Bu durumda video oyunlarını dijital medyalar olarak ele almak yerinde olacaktır, nitekim video oyunlarının herhangi bir romandan uyarlanması durumunda da romanın dijitalize edilmiş bir medyaya dönüşümü söz konusudur. Sentezlenmiş bir dijital medya olarak değerlendireceğimiz Witcher 3 video oyununu oluşturan bileşenler açık dünya sistemi, roman içerikleri, rol yapma sistemi gibi türlerden oluşmaktadır. Rajewsky (2010:51), farklı sanat formlarının kendi anlatım türlerinin dışına çıkarak başka bir medyaya dönüşmesi, sanatlararası kaynaşma, yeni sanat formları oluşturma gibi işlevleri bulunan içerik aktarıcı tüm eserlerin medyalararasılık çatısı altında ele alınabileceğini, medyalararasılığın, medyaların birbirinin içine girmesi, birbirini etkilemesi ve yeni bir medya oluşturmasına gönderme yaptığını öne sürmektedir. Sanat formlarının iç içe girmesi şeklinde yorumlanan medyalararası uyarlama süreci edebiyat medyasından video oyunu medyasına geçiş sürecinde aktarılan mesajların değişiklik göstermediği görülmektedir. Yapısı gereği görsel, işitsel ve interaktif içerik aktarımı yapan video oyunlarının mesaj iletiminde diğer medyalara nazaran oldukça yoğun ve geniş kapsamlı bir işlevi olduğu da söylenebilir. 
Medyalararası alanda birçok roman-film uyarlaması üzerinden araştırma yapılmıştır, bunun dışında şiirlerden veya romanlardan uyarlanan şarkılar, şarkılardan uyarlanan filmler, filmlerden uyarlanan oyunlar vs. üzerine birçok çalışma yapılmıştır. Fakat video oyunları ile ilgili çalışmalar halen daha çok fazla yaygınlaşmamış, video oyunlarının geneli üzerine yapılan çalışmalar dışında tek bir video oyununu ele alıp anlatı unsurları üzerinden inceleyen çalışmaların bilimsel alanda sayıca yetersiz oldukları görülmüştür. Video oyunlarının medyalararası alana girişi ise hikâye tabanlı oyunların gerçeğe yakın içerik sunmaları ile başlamıştır. Aarseth (2001), Computer Game Studies, Year One isimli yazısında ilk kez akademik sahada video oyunlarından bahsetmiş ve video oyunlarında anlatısal içerikler gibi terimler kullanmıştır. Video oyunlarını sadece sinema ve edebiyatın birleşmesinden oluşan bir görsel medya olarak görülmemesi gerektiğini vurgulamış, bu yeni medyanın herhangi diğer bir medya alanına ait yöntemsellikle değil kendine ait bazı yöntemlerle incelenmesi gerektiğini savunmuştur. Bu noktada video oyunlarının 2001 yılından itibaren ciddiye alınarak incelenmeye başladığını belirtmek yerinde olacaktır. Henüz 20 yılını tamamlamış video oyunlarının akademik alanda ele alınması hususu beraberinde birçok sorunu getirmiştir. Bu sorunlar alana ait metodolojideki boşluklar ve video oyunlarına karşı oluşan olumsuz ön yargı ve bakış açısıdır. Bu bakış açısının özellikle Türkiye genelinde video oyunlarını olumsuz yönleri ile ele alan araştırmacıların oluşturduğunu söylemek mümkündür. Video oyunlarını bu çalışmayı yakından ilgilendiren türlerine göre ayırarak ele almak ve anlatı odaklı unsurları aktarım sürecindeki etkileri üzerinde durmak gerekmektedir.

\section{Video oyunu türleri}

Video oyunları gelişen teknolojinin de etkisiyle oyuncuya gerçeğe yakın deneyimler sunmaktadırlar, fakat oyunun hikâyesi video oyunlarında oyuncuyu içine çeken en önemli unsurlardan birisidir. Çok farklı oyun türleri bulunmaktadır, fakat hikâye odaklı oyunlar özellikle macera, araştırma, rol yapma ve açık dünya türünde oyunlardır. Bazı oyunlar bu türlerin birleşiminden oluşmakta, bazıları ise birkaçının birleşiminden oluşmaktadırlar.

Oyuncunun video oyunlarında rol yapma imkânı bulduğu türde oyunlar ise kendi karakterlerini yaratma ve hikâyede rol alma gibi imkânlar buldukları rol yapma oyun türleridir. Bu tür oyunlarda hikâyenin odağında oyuncu bulunur ve oyuncu çevresindeki kişiler ve olaylarla etkileşime girerler. Oyunun ana kahramanını bazen oyuncu kendisi yaratır, fiziksel görünüşünden, ırkına, cinsiyetine ve dış görünüşüne kadar oyununun başında belirlenen özellikleri karakterine uygular ya da oyunun ana kahramanını kendine özgü bir biçimde oynayarak o karakteri kendi seçtiği bir role göre kontrol eder. Rol yapma oyunlarında oyuncunun yapmış olduğu seçimler oyunun gidişatına ve hikâyeye yön verir, hikâyede oyuncunun vermiş olduğu kararlar sonucunda hikâyenin sonu da değişmektedir. Bu tür oyunlarda roman içeriklerinin kullanılması, hikâyenin uyarlanan hikâyedeki okuyucunun "ya öyle olsaydı" diyebileceği durumlar oyuncunun oyunda verdiği kararlar doğrultusunda gerçekleşebilmektedir. Bu kararları video oyunlarında vermeye imkân veren sistem rol yapma tabanlı bir sistemdir.

\section{Rol yapma oyunları}

Rol yapma konsepti video oyunlarına Dungeons and Dragons5 isimli bir masaüstü oyundan uyarlanmıştır. Akyürek ve Özturanlı (2014:199-217), bu oyunu oynayan kişilerin canlandırdıkları karakterlerin rollerini benimseyerek oynadıklarını ve oyunu oynatan kişinin yaratmış olduğu hayali evrende hayatta kalmaya ve karakterlerini geliştirmeye çalıştıklarını öne sürmektedir. Witcher video 
oyunu gibi birçok oyunda DnD zar sistemine benzer bir sistem bulunmaktadır, oyuncu gerçekleştirdiği eylemlerde her zaman başarılı olamayabilir, çünkü başarısı oyunun başında ve sonrasında geliştirdiği becerilerine bağlı olarak şekillenir, bu beceri puanları ise oyunun oyuncunun yerine attığı rastgele zarlar ile şansa dayalı olarak sonuç bulur. Witcher oyun serisi de bu tür bir fantastik rol yapma oyunudur. Romanda bahsi geçen karakterler ile ilişkiler, hikâyenin gidişatı ve sonu oyuncunun seçimlerine bağlıdır.

Witcher 3 video oyununda yapılan seçimler karakteri farklı bir hikâye akışına sokabilir. Oyunun kilit noktalarında oyuncu bir seçim yaptığında hikâyedeki bazı karakterlerin konumunun değişimi, bazılarının hikâyeye dâhil olup olmaması gibi durumlar tetiklenebilmektedir. Bunun sonucunda oyun iyi, kötü veya normal sonla6 bitebilmektedir. Rol yapma sistemi romanın hikâyesini oyuncunun interaktif bir deneyim içerisinde yönlendirmesine imkân vermektedir. Tüm bu rol yapma ve interaktif deneyim sunan sanal evrenin Witcher ve emsali video oyunlarında açlk dünya sistemi ile sentezlenmesi de video oyun dünyasında alışılmış bir konsepttir. Açık dünya konseptinin de bu bağlamda açıklanması gerekmektedir.

\section{Açık dünya oyunları}

Açık dünya oyunları, oyuncunun oyun evreninde istediği gibi hareket edebilmesini, görevleri yaparken oyuncunun istediği görevi yapıp istemediğini yapmama imkânını bulabildiği bir sisteme sahiptirler. Çoğunlukla bilim kurgu ve fantastik temalı Fallout (Bethesda, Obsidian, 1997-2016), Borderlands (2K GAMES, 2009-2019), Skyrim (Bethesda, 2012) Stalker (x-ray Engine, 2007), Fable II (Lionhead Studios, 2008), Witcher 2,3 (Cd Project Red, 2011-2016) gibi oyunlar açık dünya konseptine sahip olarak oyuncunun karşısına çıkmaktadır. Cullen (2015:14-16), bu tür oyunların büyük bir haritaya ve çok fazla oynanamayan karaktere7 sahip olduklarını belirtmektedir. Oyuncu, hikâyenin isterse odak noktasında istemezse oynama tarzına bağlı olarak olayların dışında kalabilmektedir. Açık dünya sistemi oyuncunun istediği gibi oyun evrenini keşfedebildiği, çok düzlemli oyunlarda kullanılan bir sistemdir. Açık dünya sistemi video oyunlarının hikâye aktarma sürecine geniş kapsamlılık katan, video oyununda oyuncunun sanal olarak deneyimleyebileceği coğrafi alan oluşturan bir sistemdir. Roman serilerinden uyarlanan video oyunlarındaki yazarın oluşturduğu kurgusal evren içerisindeki tüm öğelerle sanal evrene aktarılmakta, açık dünya konsepti sayesinde oyuncu bu evrende içerikleri deneyimleme imkânı bulmaktadır. Açlk dünya sistemi, oyuncunun bu evrende istediği bölgelere yolculuk edebilmesine, roman serisinde bahsi geçen tüm coğrafi ve fiziksel mekânları gözlemleyerek deneyimlemesine imkân vermektedir. Witcher 3 video oyunu Witcher 3 ve emsali video oyunlarında sıklıkla rol yapma sisteminin açı dünya sistemi ile sentezlendiği görülmektedir. Bu sentezin hikâye aktarma sürecine etkileri ve oyuncunun hikâyeye olan etkisi üzerinde durulacaktır.

\section{Açık dünya ve rol yapma oyun türlerinin birleşimi}

Bu iki sistem çoğunlukla birlikte kullanılmaktadır, fakat istisnalar mevcuttur. Açık dünya sistemine sahip olmasına rağmen oyuncuya kendi karakterini oluşturma imkânı vermeyen oyun türlerinde tek düzlemli bir hikâye sunulmaktadır ve karakter hikâyede tamamlaması gereken göreve odaklanma veya

\footnotetext{
6 (İng: Good ending, bad ending, normal ending) şeklinde kullanımı belirli oyun türlerinde oldukça yaygındır. Oyuncunun oyununu bitirdiğinde ulaştığı farklı sonları ifade etmek için kullanılan tanımlardır. Good ending oyuncunun ulaştığı olumlu sonuçları, normal ending ne iyi ne kötü denilebilecek, nötr sayılabilecek sonuçları, bad ending ise kötü sonuçları temsil etmektedir.

$7 \quad$ NPC olarak da bilinir "non playable characters" video oyunlarında oyuncunun kontrol edemediği, bazen etkileşime geçilebilen karakterler olarak bilinmektedirler.
} 
yan görevleri yapma konusunda serbest birakılmaktadır, fakat oyuncuya rol yapma imkânı verilmediğinden kendi karakterini oluşturamamakta ve oyunda yaptı̆̆ı seçimler hikâyenin değişmesine imkân vermemektedir. Bu türe örnek olarak Shadow of Tomb Raider (Eidos,2018), Evil Within 2 (Tango Gameworks, 2017), Far Cry (Ubisoft, 2004-2019), Bioshock (2K Games, 2007-2014), Grand Theft Auto (Rockstar Games, 1997-2013) gösterilebilir, örneklerler daha da çoğaltılabilir. Bu tür oyunların rol yapma oyunlarından farkı ana karakterin oyun çizgisinin belirli olması ve karakterin oyuncuya göre şekillenme imkânının olmamasıdır. Bahsi geçen şekillenme durumu fiziksel özellikler, yetenekler, görünüş, karakterin tutumları gibi özellikler olabilir.

Açık dünya sistemi ile rol yapma sistemi bir araya geldiğinde ise oyuncu, karakteri kontrol ederken aynı zamanda oyunda benimsediği rolü yerine getirmektedir. Koch (2015) Techtimes'da yayınladığı araştırmasında, açı dünya oyunlarında oynanabilir fiziksel alanların bazılarını şu şekilde belirtmektedir; Skyrim $39 \mathrm{~km}^{2}$, Grand Theft Auto 58 km², Witcher 3 Wild Hunt genişleme paketleri ile birlikte 136 km² büyüklüğ̈̈ndedir. Bu boyutta bir alan oyuncunun mekân kavramını kırmaktadır. Açı dünya oyunlarında oyuncu mekân kavramını yitirdiğinde o dünyayı keşfetmeye zorlayan sürükleyici bir ortama uyum sağlama çabası içerisine girer. Bahsi geçen rol yapma ve açı dünya oyun türleri roman içerikleri ile birleştiklerinde ortaya deneyimlenebilecek bir roman evreni çıkmaktadır. Mekânın sınırlarının ortadan kalkması gibi bir durum, hikâyenin de içerik bakımından esnekleşmesi ve oyuncuyu da yeniden bir hikâye yazma sürecine sokması anlamına gelmektedir, zira bu noktada yalnızca hikâyenin akış sıralamasına değil, yazarın romanın uyarlanmasından evvel yaratmış olduğu anlatı evreninin de temellerinden sarsmaktadır. Artık mekânın sanal sınırlarıyla hikâyenin evvelden betimlenmiş sınırları da değişime açık bir hal almaktadır. Oyuncu roman uyarlamasının içinde hem bir karakter hem de hikâyenin yönlendiricisi konumundadır. Esasen bu durum edebiyat biliminde oldukça tartışla gelen Roland Barthes (1993:140-144), "Yazarın Ölümü” başlıklı makalesinde yoğunlaşttğ̆ gibi okur merkezli yaklaşımı da bir adım öteye taşımakta ve hikâyeyi alımlama ve yeniden üretme noktasında okur ile yazarın yanında üçüncü bir alan açarak oyuncuyu anlatı evrenine dâhil etmektedir.

\section{Roman içeriklerinin video oyunlarında kullanılması}

Roman uyarlaması oyunlar çoğunlukla fantastik edebiyat, bilim kurgu, korku, suç ve polisiye türünde eserlerden uyarlanan oyunlardır. Bu tür oyunlarda kahraman, yani oyuncu hikâyenin odağında olur ve oyunda bir nevi romandan uyarlanan hikâyeyi eserin içindeymiş gibi deneyimleme imkânı bulur. Romanın okuyucusu pasif konumdayken oyuncu hikâyede aktif konumdadır, hikâyedeki eşyalarla, karakterlerle ve olaylarla sürekli olarak etkileşim içerisindedir. Video oyunlarındaki roman içerikleri oyunlara inandırıcılık katmaktadırlar ve oyuncuya hikâyenin içerisinde bir karakter olma imkânı vermektedirler. Bu tür oyunlarda oyuncuya sunulan evrenin tarihsel geçmişi roman serilerine dayandırılmakta, bu da oyuncuya oyun evreninin deneyimleyebileceğinden daha büyük bir yapıda olduğunu hissettirmektedir. Witcher 3 video oyunu incelemesi sonucunda ulaşlan sonuçlara bakıldığında 7 romandan oluşan eserlerin video oyunu evreninin her alanında oyuncuya bir şekilde sunulduğunu tespit edilmiştir. Benzer roman uyarlaması video oyunu örneklerinin de incelenerek çalışılmasının literatüre yeni medya alanında oldukça kapsamlı çalışmalar kazandıracağı düşünülmektedir. Öte yandan bu bölüme kadar ele aldığımız tüm içeriklerin sentezinin ne tür bir medya oluşturduğunu ve bu medyanın içerik aktarım sürecini de netleştirmek gerekmektedir. 


\section{Açlk dünya, rol yapma, edebiyat sentezi ve interaktif oyun deneyimi}

Roman içeriklerinin oyunlara aktarılması sonrası oyuncu, oyunun hikâyesi ile interaktif bir ilişki içerisine girmektedir. Cullen (2015:2), bu tür oyunlarda oyuncunun hikâyedeki karakterlerle etkileşime geçebildiğini, karşılı̆̆ında hikâyedeki karakterlerin oyuncuya cevaplar verdiğini oyuncu ile etkileşime geçtiğini tespit etmiştir. Açık dünya konseptinin de eklenmesiyle bu etkileşim oyunun içindeki tüm evrene yayılmaktadır. Oyuncu, roman içeriğindeki karakterler, evren ve eşyalar ile etkileşim içerisine girer, hikâyede istediği herhangi bir yere gidip herhangi bir karakterden bilgi alabilecek konumdadır, hikâyeye yön veren ana ve yan görevleri yerine getirerek hikâyenin ilerlemesine katkıda bulunan bir yönetici konumundadır. Rol yapabilme imkânı ile oyuncu kendi seçimlerini yapabilir, kendi istekleri doğrultusunda oyunun hikâyesine yön verebilir, oyunun gidişatını değiştirebilir ve hikâyenin sonunu kararları sonucunda değiştirebilir. Tüm bu olasılıklar oyuncunun planlı veya plansız seçimlerinin sonuçları olarak meydana gelmektedir. Edebiyat medyasının içerik olarak video oyununa aktarımı oyuna anlatı unsurları açısından önemli bir katkıda bulunmaktadır. Romanlardaki tasvirlere göre oluşturulmuş ayakları yere basan bir kurgusal evren eğer oyunlaştırılmaya elverişli tasvirlere sahipse ortaya Witcher 3 video oyunu gibi başarılı bir örnek çıkabilmektedir. Guinnes dünya rekorları (2015, 140-141, 2017, 16), ansiklopedilerinde yayınlanan istatistiklere göre Witcher 3 video oyunu çlktığı sene yılın oyunu seçilmiş ve 200'den fazla ödül almıştır. Witcher 3 video oyunu, oyun dünyasında birçok açıdan örnek gösterilebilecek bir yapımdır, birçok türün birleşiminden oluşmasının, özellikle de 7 romandan oluşan geniş kapsamlı bir video oyunu olmasının etkisi önemlidir. Witcher evreni, romanları ve video oyunu hakkında sonraki bölümlerde bilgi verilecek ve karşılaştırma bölümünde uyarlama süreci incelenecektir.

\section{Witcher roman serilerinin konusu}

Witcher fantastik edebiyat türünde yazılmış olan 7 romandan oluşan bir seridir. Romanların her birinde karakterler gelişme göstermekte, evrenin tüm özellikleri okuyucuya tanıtılmaktadır, romanlarda çok fazla karaktere yer verilmiştir. Witcher roman serisinin iki ana kahramanı bulunmaktadır, bu karakterler Geralt ve Ciri'dir.

Roman serisinin çerçeve hikâyesinde iki karakterin başından geçen olaylar anlatılmaktadır. Ciri'nin peşinde birçok düşman vardır ve Geralt Ciri'yi kurtarmak istemektedir. Ciri isimli prenses, sürpriz yasası denilen bir yasa ile doğmadan önce Witcher ${ }^{8}$ Geralt'a verileceğine dair söz verilen bir çocuktur, fakat Ciri taşıdığı kadim kanın ona vermiş olduğu yeteneklerden dolayı birçok düşman tarafından farklı amaçlar için aranmaktadır. Geralt ise onu korumaya çalışmaktadır. Roman serisinin sonuna kadar Ciri ve Geralt'ın yolları ayrılıp kesişmeye devam eder, kitabın sonunda Geralt karakteri ve sevgilisi büyücü Yennefer ölmektedir, Ciri ise zaman ve mekânda yolculuk yapma yeteneklerini keşfetmiş, aynı zamanda bir Witcher olmuştur (Sapkowski, 1993-1999). Roman serisinin Witcher 3 video oyunu uyarlamasının başarısının ardından birçok medyada daha sunulduğu göz önünde bulundurulduğunda geniş kitlelere yayılmasındaki en önemli unsurun Witcher 3 video oyununun etkisinin olduğunu söylemek yerinde olacaktır.

Birçok farklı sistemin birleşiminden meydana gelen bu hikâye odaklı oyun 7 romanın hikâyelerinin görevleştirilmesi süreci ile oluşturulmuş geniş kapsamlı bir uyarlamadır. Oyundaki canavarlar,

Witcher kelimesi Türkceye Efsunger olarak cevrilebilir, fakat Witcher hem bir meslek hem de bir sinıf olarak İngilizce ve Türkçe roman çevirilerinde ve dijital platformlarda yayınlanan dizilerde İngilizce adı olan "Witcher" şeklinde kullanılmıştır. Bu yüzden bu çalışmada da Witcher olarak kullanılacaktır. 
karakterler, yerler, ülkeler ve olaylar romandaki kısa hikâyelere dayanarak oluşturulmuş, önceki oyun serileri olan Witcher 1 ve Witcher 2'deki gelişmeler ve olaylar da göz ardı edilmemiş̧tir. 2015 senesinde yılın oyunu seçilen Witcher 3 The Wild Hunt oyununun başarısı şüphesiz ki roman serisindeki hikayelerin ve karakterlerin oyuna uyarlanmaya elverişli özelliklere sahip olmalarıdır. Witcher roman serisinin sonunda kitabın kahramanları Geralt ve Ciri'nin alt ettiği düşmanlar oyuna uyarlanmamış, Geralt'ın romanda "onları alt etmenin bir yolu yok" dediği Wild Hunt isimli üç süvariden oluşan bir grup oyundaki ezeli düşmanlar olarak aktarılmıştır. Romanda ölen karakterlerden en önemli iki karakter olan Geralt ve Yennefer karakterleri oyuna aktarılmış. Oyunun hikayesi romanın hikayesi gibi Ciri'yi arayıp Wild Hunt'ın elinden kurtarılmak olarak aktarılmıştır (CD Projekt Red, 2015). Roman serisinden uyarlanan içeriklerin sanal evren yaratma sürecinde ne tür etkileri olduğunun netleştirilmesi ve video oyunlarında anlatı odaklılık hususlarına değinmek için karşılaştırmalı medyalararası inceleme yapılması gerekmektedir.

\section{Roman serisinden video oyununa uyarlanan içerikler}

Witcher roman serilerinden video oyununa uyarlanan içerikler tematik olarak incelendiğinde $r$ rç̧lık, savaş, politika, yoksulluk gibi toplumsal ve sosyal konulara, gönül ilişkileri, cinsellik, kumar gibi yetişkinlere yönelik içeriklere yer verildiği görülmektedir. Örneğin ırkçllı konusunu cücelerin ve elflerin dışlanması üzerinden aktaran roman serisinden şu alıntıyı vermek yerinde olacaktır;

\footnotetext{
"Irkçılık gözünüzü kör etmiş, Nilfgaardlılar işte böyle insanlardır!" (Sapkowski, 1994:16). "Sizin şartlarınıza göre yaşamak mı? Sizin egemenliğinizi kabul etmek mi? kendi kimliğimizi kaybetmek mi? Beraber yaşamak öyle mi?, köle olarak mı?" (Sapkowski, 1993:210).
}

Yukarıdaki alıntılarda roman serisinde Scoia Tael olarak bahsi geçen çetenin insanlarla yaşamak istemedikleri görülmektedir. Bu husumet video oyununda da devam etmekte, elfler ve cücelerin Scoia Tael adı altında insanları avlayan çeteler oluşturdukları görülmektedir. Oyuncu "Ormandaki Canavar" görevini aldığında ormanda canavar ararken Scoia Tael çetesi ile karşılaşmaktadır, insanları öldüren bir canavar olmadığını Scoia Tael çetesi olduğunu öğrenmektedir. Oyuncuya bu görev esnasında iki farklı seçenek sunulmaktadır. Oyuncu "komutanınızla konuşmak istiyorum" diyalogunu seçtiğinde barışçıl bir çözüme ulaşılmakta, fakat Oyuncu Scoia Tael çetesini yok etme yoluna da gidebilmektedir. Görüldüğü üzere ırkçılık konusu oyuncunun deneyimleyebileceği bir içerik olarak oyuncuya sunulmaktadır ve olaylara karşı oyuncunun ne gibi bir tutum takınacă̆ da oyuncuya bırakılmaktadır. Oyuncu cücelerin ve elflerin ezilen rrklar olduğunu düşünerek barışçıl bir çözüm yoluna gitmekte veya insanları öldürdükleri için onları cezalandırma yoluna gitmekte oyun tarafından özgür bırakılmaktadır. Bu durumda roman serilerinin okuyucusu pasif konumda olayları alımlarken video oyununda oyuncu olayların odak noktasında hikâyelere yön verebilme ve istediği şekilde sonuçlanmasına sebep olabilme imkânına sahiptir.

Politik içerikli olarak ele alınabilecek roman serisinden oyunlaştıılmış bir hikâye olan Prens Radovid'in suikastı (Sapkowski, 1999:404-420) görevi ve bu göreve katılıp katılmama kararının oyuncuya bırakılışı da başka bir örnek olarak ele alınabilir. "Ölümcül Plan" görevinde oyuncu Radovid'in suikastı görevini gerçekleştirmezse oyunun hikâyesinin sonunda Radovid'in savaşı kazandığı, zalim bir imparator olduğu, tüm kuzeyi ele geçirdiği, tüm insan olmayanları öldürmeye başladığı bir sinematikte anlatılmaktadır. Eğer Radovid ölürse Dijkstra hayatta kalırsa ve Redanya'nın başına geçerse Radovid'in öldürüldüğü, savaşı yine Redanya'nın kazandığı, Dijkstra'nın ülkeyi yönettiği bilgisi verilmektedir, herhangi bir ırkçı soykırımdan bahsedilmemektedir. Ĕ̆er Radovid de Dijkstra da ölürse Nilfgaard savaşı kazanmaktadır. Radovid'in ırkçı ve insan olmayanlara karşı cadı avı başlatacağını bilen oyuncu bu duruma karşı çıkıp 
Radovid'in suikastına yardım edebilme imkanına sahiptir, ya da Prens'in suikastına karışmamayı seçebilmektedir. Oyuncu ne seçim yaparsa yapsın mutlaka hikayeye bir etkisi olmaktadır. Bu noktada, çalışmada ön görülen çıkarımlardan birisi olan anlatı odaklılık hususu ve incelenmeye değer mesajların video oyununda ön plana çıktığı görülmektedir. Bu örnek üzerinden birkaç konuya değinmek mümkündür, çünkü interaktiflik unsuru hikayeyi olduğundan başka bir boyuta taşımaktadır. Roman serilerinde Sapkowski'nin çizdiği sınırların dışına çıkan oyuncu kendine özgü bir oyun deneyimi ile farklı hikayelerin yolunu açmaktadır.

Yukarıda bahsi geçen sonuçlardan her birisi oyuncunun tasavvur ederek karar vermesi gereken durumları içermektedir. Roman serilerinde ülkelerin politik durumları ve savaş ile ilgili birçok detay verilmektedir. Roman serilerinde Nilfgaard ve diğer ülkelerin savaşı oldukça geniş kapsamlı ele alınmakta, sonuç olarak Elfler ve insan olmayan tüm ırklar vatanlarından sürgün edilmekte, Scoia T'ael çeteleri Nilfgaard'a karşı mücadelelerine devam etmektedirler (Sapkowski, 1999, 268-311). Oyun uyarlamasında da Scoia Tael, ırkçlık ve baskıya karşı direniş ile ilgili içerikleri aktarma görevini üstlenen bir aracı olarak kurgulanmışken, Nilfgaard baskıcı ve istilacı bir imparatorluk olarak oyuncuya aktarılmaktadır. Oyuncu hem tüm bu mesajları almakta hem de bu durumları değiştirebilecek kararlar vermektedir. Bu durumda roman serisinin sadece okuyucuya sunabildiği bir bilgi, oyunda oyuncunun iyi veya kötü olarak değerlendirdiği durumlara kendi kişisel görüşlerine göre müdahale edebildiği bir içeriğe dönüşmektedir. Bu durumda okuyucu roman serilerinde aktarılan hikayeleri tasavvur edip kendi görüşlerine göre yargılarken, oyuncu bu hikayelerde gördüğü haksızlıklara, yanlış olduğunu düşündüğü durumlara müdahale edebilmektedir. Bu interaktiflik oyuncuya hikayede söz hakkı vermekte, bir nevi oyuncuya yazarın evrenine hâkim olma imkanı tanımaktadır.

Başka bir örnek olarak yine insan olmayanlara ve inancı olmayan kişilere hoşgörüsü olmayan bir tarikattan da her iki medyada da bahsedildiği görülmektedir. Roman serisinde şu şekilde bir diyalog bu konuda örnek gösterilebilir; "insan olmayanlar ve diğer tüm tuhaf yaratıklar insanlık tarihinden silinmelidirler" (Sapkowski, 1999:414). Bu alıntı romanda bir ebedi ateş tarikatı rahibinin sözlerinden yapılmıştır. Roman serilerinden oldukça tutarlı şekilde uyarlanan bir diğer içerik de aşırı dinci grupların diğer ırklara karşı hoşgörüsüz olmasıdır. Oyunda edebi ateş tapınağına bağlı rahiplerden bazıları şehir sokaklarında vaaz verirken görülmektedirler, eğer oyuncu bu rahiplerinden birisi ile konuşursa, rahip Geralt'a bir mutant ve kaçık olduğunu, kazığa bağlanıp yakılması gerektiğini söylemektedir. Oyunda bu rahip ile ilgili herhangi bir görev bulunmamaktadır, sadece Novigrad şehrinin Hiyerarşi meydanında, şehrinin merkezinde insanlara vaaz vermektedir (CD Projekt Red, 2015a). Din ve aşırı dinci gruplar, nefret söylemleri gibi içeriklerin de video oyunlarında kullanıldığı bilinmektedir, oyuncunun bu tarz konuları oyunun içerisindeki bir karakter olarak deneyimlediği düşünüldüğünde video oyunlarının bu tür mesajları iletmek için oldukça başarılı mesaj iletim sürecine sahip bir medya olduğunu söylemek yanlış olmayacaktır. Witcher roman oyun uyarlamasında aile ilişkileri, dostluk, romantizm, yalnızlık gibi birçok motif de kullanılmıştır. İçeriklerle ilgili sayısız örnek sunulabilir, neredeyse anlatı odaklı olarak ele alınabilecek her oyunun mesaj verme ve hikâye anlatma kaygısı bulunmaktadır, roman içeriklerinden uyarlanıp uyarlanmadığına bakılmaksızın video oyunlarının sosyal ve toplumsal konuları ne şekilde işledikleri, oyuncuya ne şekilde aktardıkları ile ilgili de birçok çalışma yapılabilir. Video oyunlarındaki hikâyeler belki oyunlaştırlarak oyuncuya sunulmakta, oyuncunun hangi görevleri kabul edip etmeyeceği de seçenek olarak sunulmaktadır, fakat mesaj aktarımı neredeyse her görevde bulunmakta, oyuncu bir hedefe odaklanırken istemli veya istemsiz birçok mesajla karşlaşmaktadır. Witcher ve emsali rol yapma, açık dünya türünde oyunlarda ise bu durum çok daha etkili bir mesaj aktarım sürecine dönüşmektedir. Öyle ki oyuncu sanal bir evrende özgürce dolaşmakta, kendi oluşturmuş olduğu karakteri o sanal evrende kontrol etmektedir. Oyuncunun sanal evrendeki bir 
yansıması olan karakteri sürekli olarak birtakım mesajlara maruz kalmaktadır. Bu mesajların yukarıda verilen örneklerde olduğu gibi toplumsal ve sosyal mesajlar oldukları da göz önünde bulundurulduğunda video oyunlarının diğer medyalara nazaran çok daha etkili bir dijital iletişim aracı olduğunu söylemek ve diğer tüm medyalar kadar analiz edilmeye ihtiyacı olan eserler olduğunu ifade etmek yerinde olacaktır.

\section{Witcher video oyunu uyarlaması ve oyuncunun hikâyeye yön verebilmesi}

Fantastik edebiyat türünde 7 romandan oluşan Witcher serisinin video oyununa dönüşümü sonrasında romandaki hikâyelerin tarihsel bir arka plan olarak kullanıldığı görülmüştür. Witcher 3 The Wild Hunt video oyununda romandaki neredeyse tüm karakterler bir şekilde oyuna uyarlanmıştır, romanla ilgili referanslar ve detaylar oyunda birçok yerde oyuncunun karşısına çıkmaktadır. Romanda bahsi geçen karakterler ile oyuncu istediği şekilde etkileşime geçebilmektedir. Hikâyede bahsi geçen ülkelere seyahat edebilmekte ve oyunun farklı sonlarından birisini yaptı̆̆ı seçimler neticesinde tetikleyebilmektedir (CD Projekt Red, 2015).

Roman serisinde ve oyunda ana kahramanlar olarak ele alınabilecek Geralt ve Ciri'yi kontrol eden oyuncu diğer karakterler ile olan ilişkilerinde sürekli seçimler yapmaktadır. Oyuncu yönlendirdiği ana karakter olan Geralt'in nasıl giyineceğine, hangi teçhizatı yanında taşıacağına, yeteneklerini nasıl geliştireceğine, kiminle gönül ilişkisi yaşayabileceğine, hangi karakterle silah arkadaşı olabileceğine, hangi karakterleri kurtarıp hangilerini kurtarmayacağına karar vermektedir (CD Projekt Red, 2015). Roman serisinde ise okuyucu pasif konumda sadece Geralt ve Ciri'nin hikâyelerini tasavvur ederken, oyunu oynayan kişi bu hikâyede olayların odak noktasındadır. Hikâyeye yön vererek oyunda sınırlanmış farklı yol ayrımlarına girer, vermiş olduğu kararlar neticesinde alternatif hikâyelerin kilidini açarak kitabın yazarının ve oyun yapımcılarının oluşturmuş olduğu hikâyenin farklı sonlarından birisine ulaşır. Bu hikâye bir bakıma oyuncunun özgün oyun deneyiminin ürünü olarak görülebilir. Bu duruma örnek olarak Geralt ve Ciri karakterlerini oynayan oyuncunun yaptığı seçimler sonucunda oluşturdukları hikâyeler ve alternatif sonlar ile ilgili örnekler vermek yerinde olacaktır.

\section{Geralt'in oyundaki gönül ilişkileri ve hikâyesinin farklı sonları}

Romandaki Geralt karakteri de Oyundaki Geralt karakteri de birçok kadın ile gönül ilişkileri yaşama imkânı bulmaktadır. Gönül ilişkileri ile ilgili romanda verilen olaylar video oyununda geçmiş zamanda yaşanmış ilişkiler olarak gündeme gelmektedir. Geralt'in roman serilerinde Yennefer, Triss, Shani karakterleri ile gönül ilişkileri ve cinsel birlikteliklerine değinildiği görülmektedir. Video oyununda da bahsi geçen karakterler uyarlanmış, fakat tüm ilişki seçimleri oyuncunun kararlarına bağlıdır. Hikâyenin sonuna kadar oyuncunun seçimleri istatistiksel veriler olarak kaydedilerek oyunun sonundaki sinematikte oyuncuya bitirdiği hikâye ile ilgili bilgiler verilmektedir. Oyuncu, oyunun sonunda yaptığı tüm seçimlerle oluşturmuş olduğu yeni hikâyeyi, kendi özgün hikâyesinin sonuçlarını ve bu sonuçların evrendeki etkilerini görebilmektedir. Oyuncunun interaktif katılımı ile oluşturmuş olduğu dijital medyanın çıktısı olan bu hikâyenin alternatif sonlarına örnek olarak birkaç alıntı vermek yerinde olacaktır.

\section{Yennefer ile mutlu son}

Roman serisinin sonuna kadar Yennefer ve Geralt karakterlerinin ilişkileri inişli çıkışlı tabir edilebilecek bir süreçten geçmektedir. Roman serisinin sonunda birlikte ölen karakterler (Sapkowski, 1999: 488) 
için Sapkowski'nin roman içerisinde oluşturduğu kurgusal bir karakter tarafından yazılmış gibi gösterilen bir masalda Yennefer ve Geralt karakterlerinin kavuştuklarından bahsedilmektedir;

"Büyücü ve Witcher evlenirler ve mutlu bir şekilde yaşarlar. Witcher bir kalp krizinden ölür, ardından da büyücü ölür. Nedeni bilinmez, belki özlem belki de üzüntüden. Ama zaten masallara kim inanır ki?" Flourens Delannoy - Masallar (Sapkowski, 1999:459).

Roman serisindeki alternatif sonların oyunda oyuncunun seçimlerine göre tetiklenmesine örnek olarak gösterilebilecek bir durum burada da tespit edilmektedir. Birkaç seçim sonucunda oyuncunun romanda bahsi geçen sona ulaşabilme imkânı bulmaktadır. Roman serilerinde oyuncunun seçimlerine bağlı olarak "son dilek" görevinde Yennefer'e destek olması ve "ya şimdi ya hiç" görevinde triss ile herhangi bir romantizm yaşamaması durumunda Yennefer ile emekli olup birlikte yaşamaktadırlar. Oyundaki sonlardan birisi romanda verildiği şekliyle ele alınmıştır (CD Projekt Red, 2015). Yennefer karakteri oyunda oyuncunun tek alternatifi değildir. Roman serilerindeki alternatif gönül ilişkileri oyuncuya bir seçim olarak sunulduğundan bunun hem oyundaki uyarlama hikâyenin değişimi hem de oyunun hikâyesinin sonuna etkisi olduğu görülmektedir.

\section{Triss ile mutlu son}

Triss karakteri roman serisinde de oyunlarda da Geralt ile gönül ilişkisi olan bir kadın olarak tasvir edilmektedir. Triss karakteri Geralt ile geçmişte ilişkisi olan bir karakter olarak ele alınmaktadır. Romandaki bu durum Yennefer karakteri ile Triss arasında geçen bir tartışmada geçen diyalogdan örnek verilebilir; "Bu halini biliyorum, gizlice arkamdan iş çevirip Geralt ile yatmaya başladığında da böyleydin!" (Sapkowski, 1997:238). Romanda bahsedilen Triss ile olan ilişki oyunda da oyuncunun seçimlerine bağlı olarak devam edebilmektedir, oyuncu "ya şimdi ya hiç" görevinde Geralt, Triss'in gemiye binip gitmesine izin vermezse ve onu sevdiğini açılarsa Triss ile oyunu mutlu sonla bitirme imkânı bulabilmektedir (CD Projekt Red, 2015). Triss karakteri ve Yennefer karakteri dışında Geralt karakterinin gönül ilişkisi yaşayabileceği birçok alternatif karakter bulunmaktadır ve oyun tüm seçimleri oyuncuya bırakmakta, oyuncuyu herhangi bir seçime zorlamamaktadır. Oyuncunun bu durumdaki özgürlüğü oyunda kendi Geralt versiyonunu yaratma imkânı vermektedir. Bu durumda da oyuncunun kendi özgün hikâye seçimleri ile oluşturduğu alternatif hikâyeler açılmaktadır.

\section{Geralt'in yalnız kaldığı son}

Oyuncu oyunun sonuna kadar hem Triss hem de Yennefer ile birlikte olmak isterse tuzağa düşürülüp iki kadın tarafından yatağa bağlanmakta ve yalnız kalarak Witcher mesleğine devam etmek zorunda kalmaktadır (CD Projekt Red, 2015). Video oyunu medyasının kendine has özelliklerinden birisi olan oyuncuya ana hikâye akışının yanında alternatif hikâyeler sunması durumu, sınırlandırılmış da olsa oldukça geniş kapsamlı bir hikâye çeşitliliği ortaya çıkarmaktadır. Sınırlandırılmış olması oyuncunun var olan alternatif hikâyeleri seçimleri doğrultusunda aktifleştirmesi ile hikâyesine dâhil etmesi anlamına gelmektedir. Oyuncunun oyunda sürekli olarak karar verdiği düşünülürse bir oyuncunun neredeyse başka bir oyuncu ile aynı oyun deneyimini yaşamış olmasına imkân olmayacağı söylenebilir. Oyuncunun görevlerdeki kararları, hikâyedeki karakterler ile ilişkileri ve olaylara karşı tutumları açısından mutlaka farklılıklar oluşmaktadır. Oluşturulan farklı hikâyelere örnek olarak Ciri karakterinin hikâye çizgisindeki kırılma noktaları da gösterilebilir. 


\section{Ciri karakterinin oyundaki üç farklı sonu}

Roman serilerinde karakterin hikâyesinde kırılma noktaları veya dönüm noktaları olarak adlandırılabilecek bölümler video oyununda oyuncunun oyun boyunca yapmış olduğu seçimlere bağlı olarak oyunun farklı sonlarına dönüşmektedirler. Bu sonlar roman serilerinde ve video oyununda üç farklı son olarak ele alınabilir. Witcher 3 video oyununda Ciri'nin hikâyesinde üç farklı son bulunmaktadır.

\section{Ciri'nin Prenses olduğu son}

Oyunda normal son olarak adlandırılabilecek olan bu son roman serisinde bir dönüm noktası olarak okuyucuya sunulmakta, Ciri ile Geralt ayrılmakta ve Ciri babasına dönmektedir (Sapkowski, 1999: 369). Bu anda Okuyucu Ciri'nin hikâyesinin romandaki sonu olduğunu, Hükümdar olan babasının sarayında prenses olacağını düşünmektedir. Fakat sonrasında Ciri karakteri babasının onu geri gönderdiğini söyler ve Geralt'a geri döner (Sapkowski, 1999:373). Oyunda da Ciri'nin babasına dönmesi gibi bir ihtimal var, eğer oyuncu Ciri'nin Witcher olarak kalmasını başaramazsa "Bir Şeyler Biter Bir Şeyler Başlar" isimli görevin sonunda Ciri karakteri prenses olmaktadır (CD Projekt Red, 2015). Bu durumda roman serisinde verilen Ciri karakterinin prenses olduğu dönüm noktası oyunda bir son olarak oyuncuya sunulmaktadır. Ciri'nin prenses olduktan sonra Nilfgaard imparatorluğunu ne şekilde yönettiği, ülke politikasına etkisi, savaşların ve azınlıkların durumu da bu seçimler doğrultusunda değişmektedir. Burada interaktif hikâye oluşturma süreci dışında anlatı odaklı olarak ele alınabilecek örnekler bulunduğunun altını çizmek gerekmektedir, Witcher 3 ve emsali oyunların sadece eğlence odaklı eserler olarak tasarlanmış oldukları öne sürülürken bu tür detaylar görmezden gelinmektedir. Video oyunu araştırmalarını video oyunlarını deneyimlemeyen araştırmacılar tarafından yorumlanmasının bilimsel kabul edilemeyeceği görülmektedir.

\section{Ciri'nin Witcher olduğu son}

Oyunun iyi sonu olarak bilinmektedir ve oyuncunun bu sonu elde etmek için Ciri karakteri ile olan ilişkilerini en üst seviyede tutmalıdır. Roman serisinin sonunda Geralt ve Yennefer öldükten sonra da Ciri kendisini Witcher olarak görmektedir; "Bu dünyada da bir witcher'a ihtiyaç olduğuna her türlü bahse girerim" (Sapkowski, 1999:493). Oyunda da "bir şeyler biter bir şeyler başlar" isimli görevde Ciri'nin Witcher olarak kaldığı bir son mevcuttur. Geralt ile Ciri'nin Witcher olarak hayatlarına devam ettikleri bu son yine oyuncunun Ciri ile ilgili verdiği tüm kararların olumlu yönde olmasının sonucunda meydana gelmektedir (CD Projekt Red,2015). Roman serilerinde başından beri okuyucunun beklediği sona video oyununda oyuncu seçimleri ile ulaşabilmektedir. Oyuncu mutlak iyi son ile hikâyeyi tamamlamasına rağmen oyun evreninde Ciri karakteri ve diğer karakterler halen daha etkileşime geçilebilir karakterler olarak sanal evrende var olmaktadırlar. Ciri karakteri ile iyi sonla biten hikâyenin ardından oyuncu "Kan ve Şarap" isimli genişleme paketinde Toussant ülkesindeki malikânesinde Ciri ile aynı evde yaşamaktadır. Fakat eğer oyuncu Ciri karakterinin prenses olduğu sona ulaşmışsa veya Ciri'nin öldüğü sona ulaşmışsa Ciri karakteri Witcher evreninde var olmamaktadır. Üçüncü son ise Ciri'nin öldüğü son olarak görülebilir.

\section{Ciri'nin öldüğü son}

Roman serisinde okuyucu Ciri'nin içerisinde olduğu tehlikelerden birisinde ölebileceğini düşünebiliyor, birçok kez alıkonulan ve okuyucunun kurtulamayacağını tasavvur edebileceği durumlar okuyucuya 
dönüm noktaları olarak sunulmaktadır. Bu dönüm noktalarından birisi de oyuncunun Ciri ile ilgili yapmış olduğu negatif seçimlerin sonucu olarak tetiklenebilmektedir. Oyuncu eğer "savaş meydanında kan", "son hazırlıklar", "kadim kanın çocuğu" görevlerinde Ciri'ye destek olmazsa Ciri'nin oyunun sonunda ölmesine sebep olabilmektedir (CD Projekt Red, 2015). Yukarıda verilen örneklerdeki gibi oyuncunun yaptığı seçimler hikâyenin belirli noktalarında kırlmalara sebep olmaktadır ve oyunun sonunda karakterlerin hikâyelerinin sonları farklı bitebilmektedir.

Roman serilerindeki kırılma noktalarının oyuncuya mutlak son olarak sunulması medyalararasılık, anlatı odaklılık ve interaktif oyun deneyimi açısından oldukça önemli örneklere sahiptir. Rol yapma sistemi oyuncunun özgün oyun deneyimi ile hareket edebilmesine imkân vermektedir. Oyuncu yaptı̆̆ı seçimlerin sonuçları olacağını bilmekte, karakterinin rolünden çıkmamaya çalışmaktadır. 200 saatlik bir görev listesi olan oyunda oyuncu oynattığı karakter ile kendisini özdeşleştirmekte, oyun ile arasında bağ kurmaktadır. Açık dünya sistemi oyuncunun sanal evrende istediği şekilde yolculuk edebilmesine, istediği yere ulaşabilmesine imkân vermektedir. Böylece oyuncu özgürce her türlü içerik ile etkileşime geçebilmektedir. Roman içeriklerinin kullanılması ise oyuncuya arka planı ve tarihsel geçmişi olan bir evrende yaşadığı hissini vermekte, karakterlerin roman serilerindeki fiziksel ve davranışsal özelliklerine uygun hazırlandığını hissettirmektedir. Böylece oyuncu özgün oyun deneyimini interaktif bir oyuncu hikâyesi olarak sonlandırmaktadır.

\section{Sonuç}

Witcher 3 The Wild Hunt, 7 romandan oluşan bir video oyunu uyarlamasıdır ve romanın çerçeve hikâyesi oyuncunun seçimleri ile şekillenen alternatif olaylarla değişime uğrayan bir hikâye olarak oyuncuya sunulmaktadır. Verilen kararların oyuncuya ve hikâyenin seyrine doğrudan bir etkisi olmaktadır ve oyun bu nedenle diğer medyalardan farklı olarak interaktif bir medya olarak tanımlanmaktadır. Bu nedenle oyuncuya bir anlamda kendi hikâyesini oluşturma firsatı sunmaktadır. Açık dünya sistemi üzerine kurulmuş rol yapma türündeki hikâye tabanlı video oyunları, sinema, edebiyat ve dijital medyalar gibi farklı türlerin bir araya gelmesi ile oluşan medyadır. Roman içerikleri video oyunlarına ve oyuncuya mekân, zaman, tarihsel arka plan, karakterlerin geniş tasviri ve geçmişleri ile ilgili bilgiler verirken, hikâye evreninin geniş bir tanımı ve oyuncuyu içine çeken bir atmosfer sunmaktadırlar. Hikâye tabanlı oyunlardaki roman uyarlamalarının video oyunlarına olan etkileri hem oyunun içeriği hem de hikâyesi açısından oldukça önemlidir. Oyunlardaki interaktiflik oyuncuya hikâyedeki karakterlerle, mekânlara, zamana, dekorlara kısacası oyun evrenindeki her şeyle etkileşime geçme imkânı tanımakta ve bu interaktiflik oyuncunun hikâyeye daha çok çekilmesini sağlamaktadır. Rol yapma tabanlı sistem ise oyuncuya hikâyenin içinde istediği gibi davranabilmesi imkânını vererek, olaylara oynadığı karakterin rolüne bürünerek karar vermesini sağlamaktadır. Açık dünya konsepti oyuncunun hikâyenin evreni içerisinde istediği gibi dolaşabilmesine, özgürce dilediği yere gidebilmesine, oyunun ana görevine veya yan görevlere bağlı veya bağımsız olarak sanal evreni keşfedebilmesine imkân vermektedir. Roman uyarlaması oyunlar anlatı odaklı olarak ele alındıklarında oyuncunun da bu anlatıda bir yeri olduğu, bir nevi hikâyeye yön verebildiği görülmektedir. Medyalararasılık bağlamında bu durum incelendiğinde roman medyasının içeriklerinin sanal bir yaşantısal ortam içinde oyuncuya sunulduğu görülmektedir. Oyuncunun ise video oyunu medyasındaki hikâyelere yön vererek kendi hikâyesini oluşturduğu oynanamayan oyun karakterlerinin ve kendi hikâyesinin sonunu belirlediği görülmektedir. Edebiyat medyasının anlatısal özelliklerinin bu tür yeni medyalar sayesinde sabit ve değişmez bir biçimde ele alınmasından çok, yeni medyaların teknik imkânları doğrultusunda yeniden tanımlanabileceği görülmektedir. Hikâye tabanlı video oyunlarının naratolojik, hikâye anlatma amacı da taşıyan medyalar oldukları için oyunbiçimsel yani ludolojik bir 
bakış açısı ile hikâyeden bağımsız incelenmelerinin uygun olmayacağı görülmektedir. Medyalararasılık çerçevesinde incelenebilecek Witcher emsali diğer video oyunlarına; Skyrim, Dragon Age, Fallout, Metro gibi örnekler verilebilir. Bu noktada vurgulanabilecek bir diğer nokta ise her video oyununun hikâye anlatma işlevinin olduğu, bazılarının tek düzlemliyken, bazılarınınsa çok geniş kapsamlı ve çok düzlemli oyunlar olmalarıdır. O halde birkaç sistemin birleşiminden oluşan anlatı odaklı video oyunları ile, içerisinde barındırdığı sistemlerin aktarılan hikâyelere olan etkileri ele alınmalıdır. Bu çalışmada rol yapma ve açık dünya sistemleri Witcher 3 video oyunu örneği üzerinden açılanmış, hikâye aktarımında bu sistemlerin ne tür işlevleri olduğu açıklanmıştır. Benzer incelemeler farklı türde video oyunları üzerinden yapılabilir, video oyunu medyaları da anlattıkları hikâyeler açısından ele alınarak tıpkı edebiyat ve sinema medyaları gibi medyalararasılı̆̆ın kavramlarından ve yaklaşımından faydalanılarak incelenebilirler. Video oyunlarının sanat formu olup olmadıkları, anlatı odaklı medyalar olup olmadıkları, ne şekilde ele alınacakları ve yöntemsel yaklaşım sorunlarının aşılması açısından bu tür çalışmalar ayrıca sosyal bilimler alanında önem arz etmektedirler.

\section{Kaynakça}

Aarseth, E. (2001). Computer Game Studies, Year One. Erişim Adresi: www.gamestudies.org/o101/ Erişim: 24 Ocak 2020.

Aarseth, E. (2003). Playing Research: Methodological Approaches To Game Analysis, Kopenhag: It University Of Copenhagen, Computer Game Theory Compendium.

Aytaç, G. (2005). Edebiyat ve Medya, Ankara: Hece.

Akyürek, F., Özturanlı G. (2014). Saraydan Sokağa Oyun. İstanbul: Kabalcı .

Barthes, R. (1993). Yazarın Ölümü, Çev: Hüsamettin Çetinkaya, Edebiyat Eleştiri, Sayı 4, Güz 1993, S.140-144.

Bulduk, N., Canatak, M. A. (2019). Dijital Çă̆ Türk Edebiyatı Ve Medyalararasılık Tartışmaları, İstanbul: Hiperlink Yayınları.

Can, M. Z.; Türkmen, B. (2017). Bilgisayar Oyunlarının Yabancı Dil Eğitimine Katkısının Araştırılması: Anadili Türkçe Olan 100 Yükseköğretim Öğrencisi Üzerinde Yapılan Araştırma Örneği. Tarih Okulu Dergisi. Yll 10, Sayı XXXI, ss. 399-435

CD Projekt Red. (2015). Witcher 3: Wild Hunt, Bilgisayar, Play Station4, Xbox One Video Oyunu, Warsaw, Polonya.

CD Projekt Red. (2015a) Witcher 3: Wild Hunt, Hearts of Stone, Bilgisayar, Play Station4, Xbox one Video Oyunu, Warsaw, Polonya.

Consalvo M., Dutton N. (2006). Game Analysis: Developing A Methodological Toolkit For The Qualitative Study Of Games, Erişim Adresi: www.gamestudies.org/0601.articles/consalvo_dutton Erişim Tarihi: 24.01.2020.

Cullen, T. (2015). Modelling Environmental and Temporal Factors on Background Characters in Open World Games, University of Dublin, Trinity College, Ireland.

Demirbaş, Y. (2017). Oyun Çalışmalarında Dijital Anlatı İle Oyun Biçimi Karşıtlı̆̆ı Ekseninde Süren Tartışmalara Farklı Bir Bakış.

Frasca, G. (2003). Ludologists Love Stories, too: Notes From a Debate that Never Took Place. DiGRA Konferans1, Erişim adresi: www.ludology.org/articles/Frasca_LevelUp2003.pdf Erişim tarihi: 12.08.2017 Hacettepe Üniversitesi İletişim Fakültesi Kültürel Çalışmalar Dergisi, S.2017, 4(2): s: 352-373.

Denizel, D. (2012). Sanatın Yeni Evresi Olarak Bilgisayar Oyunları, Felsefe ve Sosyal Bilimler Dergisi, Bahar, S:13, s.107-143.

Guinness World Records. (2015). Gamer's Edition, Publisher: Guinness World Records Limited. 
Guinness World Records. (2017). Gamer's Edition, Publisher: Guinness World Records Limited.

Işığan A. (2012). İnteraktiflik Sorunu Çerçevesinde Video Oyunu Anlatı İlişkisi. Yayınlanmamış Doktora Tezi, Ankara Üniversitesi Sosyal Bilimler Enstitüsü, Ankara.

Juul, J. (2001). Games Telling Stories, Erişim Adresi: www.gamestudies.org/o101 ErişimTarihi: 24 Ocak 2020.

Kayaoğlu, E. (2009). Edebiyat Biliminde Yeni Bir Yaklaşım: Medyalararsılık. İstanbul : Selenge.

Keleş, A. (2017). Franz Kafka'nın Dava ve Şato Romanlarının Film Uyarlamaları Örneğinde Edebiyat ile Film Arasında Medyalararasılık Îlişkileri, Sakarya Üniversitesi Sosyal Bilimler Enstitüsü, Yayımlanmamış Doktora Tezi.

Koch, C. (2015). How Big Is Witcher 3, Erişim Adresi: www.techtimes.com/articles/50240 Erişim Tarihi: 24.01.2020.

Perkins, K. E. (2010). Lifesigns: Successful Storytelling in Open-World Games, Media Arts and Studies, Ohio University, Ohio.

Rajewsky, O. I. (2010). Border Talks: The Problematic Status of Media Borders in the Current Debate About Intermediality, in: Lars Elleström (ed.), Media Borders, Multimodality, and Intermediality, Basingstoke: Palgrave Macmillan, S.51 s. 51-68.

Sapkowski, A. (1993). Der Letzte Wunsch, München: Deutscher Taschenbuch Verlag GmbH \& Co. KG.

Sapkowski, A. (1997). Der Schwalbenturm, München: Deutscher Taschenbuch Verlag GmbH \& Co. KG.

Sapkowski, A. (1999). Die Dame Vom See, München: Deutscher Taschenbuch Verlag GmbH \& Co. KG.

Tüker, Ç. (2014). Video Oyunları Bir Sanat Formu Olabilir Mi? İstanbul: Kabalcı . 